\title{
PENGEMBANGAN LKS IPA BIOLOGI KELAS VIII SMP BERORIENTASI PADA PENDEKATAN KETERAMPILAN PROSES SAINS
}

\author{
Fitri Arsih \\ Program Studi Pendidikan Matematika Sekolah Tinggi Keguruan Ilmu Pendidikan Yayasan \\ Pendidikan Marangin Bangko Jambi \\ Korespondensi: Jl. Jenderal Sudirman Kab. Merangin Bangko-Jambi. e-mail: Fitri79@yahoo.co.id
}

\begin{abstract}
At present, it is suspected that students study biology as product and memorize related concepts, theories and laws. Conversely, biology as content or product, process or methods, attitude and technology are rarely applied that makes the subject not as a whole piece and less interesting. Such phenomena challenges the teacher to be more creative and innovative in developing practical learning supports which are simple and easy to be used by both students and teachers. This research aimed at developing worksheets (LKS) for biology subject intended for grade 8 of junior high school students under the topic of photosynthesis employing valid, practical and effective science process skill approach. This study belonged to research and development one. Learning support is developed by means of Four-D (Define, Design, Develop and Disseminate). 'Disseminate' is not done. Data collections were conducted by validating and trying out of the learning support. Validations were conducted by six experienced and qualified validators while try out was conducted by applying it to the grade 8 students of SMP Dedikasi Edukasi Kualiva (DEK) Padang to figure out practicality and effectiveness. The study showed that the worksheet using environment-based science process skill approach was in very valid category. Students' responses toward the worksheet showed positive result with an average response was $\geq 80 \%$. It can be concluded that the worksheet was valid, practical and easy to use.
\end{abstract}

Kata kunci: LKS, keterampilan proses sains

\section{PENDAHULUAN}

$\mathrm{P}$ endidikan merupakan hal yang sangat penting dan mendasar dalam meningkatkan kualitas kehidupan manusia, menjamin perkembangan sosial, teknologi, maupun ekonomi. Saleh (2007:1) mengemukakan bahwa pendidikan satu-satunya wadah kegiatan pembelajaran yang berfungsi untuk menciptakan sumber daya manusia yang bermutu tinggi. Sekolah adalah salah satu wadah kegiatan pendidikan yang berfungsi sebagai pencipta sumber daya manusia. Salah satu mata pelajaran yang diajarkan di sekolah adalah pelajaran natural sains (ilmu pengetahuan alam). Natural sains merupakan ilmu pengetahuan yang terorganisir secara sistematis berupa fakta, konsep, maupun generalisasi tentang alam semesta beserta seluruh isinya yang telah diuji melalui serangkaian proses ilmiah berdasarkan observasi dan eksperimentasi. Dengan demikian, pembelajaran sains meliputi tiga sisi yaitu produk, proses, dan nilai.

Biologi adalah salah satu bagian dari natural sains mengkaji berbagai persoalan yang berkait dengan berbagai fenomena makluk hidup dari berbagai 
tingkat organisasi kehidupan dan interaksinya dengan faktor lingkungan, serta dimensi ruang dan waktu. Agar peserta didik dapat mempelajari biologi dengan benar, maka biologi harus diperkenalkan secara utuh, baik menyangkut objek, persoalan, maupun tingkat organisasi dari benda-benda yang ada di dalam jagad raya (Anonim, 2009a)

Pembelajaran ilmu biologi mengandung empat unsur utama, pertama : unsur sikap, rasa ingin tahu, fenomena alam, makhluk hidup, serta hubungan sebab akibat yang akan menimbulkan masalah baru yang dapat dipecahkan melalui prosedur yang benar, sehingga ilmu sains bersifat open ended. Kedua proses, prosedur pemecahan masalah melalui metode ilmiah. Ketiga produk, berupa fakta, prinsip, teori dan hukum dan yang keempat adalah aplikasi, penerapan metode ilmiah dan konsep sains dalam kehidupan sehari-hari (Badan Standar Nasional Pendidikan, 2006:5)

Dalam proses pembelajaran ilmu biologi keempat unsur itu diharapkan dapat muncul sehingga peserta didik mengalami proses pembelajaran secara utuh, memahami fenomena alam melalui kegiatan pemecahan masalah, metode ilmiah, dan menuju cara ilmuan bekerja dalam menemukan fakta baru. Hal yang sama juga diungkapkan oleh Cain dan Evan (Rustaman, 2003:88) bahwa biologi mengandung empat hal, yaitu konten atau produk, proses atau metode, sikap, dan teknologi.

Menurut Blomm (Sudijono, 2008: 49) pengelompokan tujuan pendidikan itu harus senantiasa mengacu pada tiga jenis domain yang melekat pada diri peserta didik, yaitu ranah proses berpikir (cognitive domain), ranah nilai atau sikap (affective domain) dan ranah keterampilan (psikomotor domain). Ranah kognitif adalah ranah yang mencakup kegiatan mental (otak) dan ranah psikomotor adalah ranah yang berkaitan dengan keterampilan (skill) atau kemampu- an bertindak setelah seseorang menerima pengalaman belajar tertentu.

Namun yang sangat disayangkan kecenderungan pembelajaran biologi pada masa sekarang, peserta didik hanya mempelajari produk, menghafal konsep, teori dan hukum. Keadaan ini diperparah oleh pembelajaran yang berorientasi pada tes atau ujian, akibatnya ilmu biologi sebagai konten atau produk, proses atau metode, sikap dan teknologi sangat jarang diaplikasikan dalam pembelajaran. Pengalaman belajar yang diperoleh di kelas tidak utuh dan tidak berorientasi tercapainya standar kompetensi dan kompetensi dasar. Pembelajaran lebih bersifat teacher centered, guru hanya menyampaikan materi sebagai produk dan peserta didik menghafal informasi faktual.

Fakta di lapangan menunjukkan bahwa banyak peserta didik yang cenderung menjadi malas berpikir secara mandiri. Cara berpikir yang dikembangkan dalam kegiatan belajar belum menyentuh domain afektif dan psikomotor. Alasan yang sering dikemukakan oleh para guru adalah padatnya materi, keterbatasan waktu, sarana, lingkungan belajar dan jumlah peserta didik per kelas yang terlalu banyak. Beberapa guru khususnya bidang studi IPA biologi masih ada yang belum mampu membuat bahan pembelajaran sendiri yang berorientasi pada kompetensi peserta didik.

Untuk dapat melatih ranah kognitif, afektif, dan psikomotor maka pendekatan pembelajaran yang digunakan harus mampu membimbing peserta didik mencapai standar kompetensi yang diharapkan, salah satunya adalah pembelajaran dengan pendekatan Keterampilan Proses Sains (KPS). KPS merupakan pendekatan pembelajaran yang berorientasi kepada proses IPA. KPS melibatkan keterampilan-keterampilan kognitif atau intelektual, afektif (sosial) dan keterampilan psikomotor. 
Menurut Rustaman (2003: 89) keterampilan kognitif terlibat dengan melakukan keterampilan proses siswa menggunakan pikirannya, keterampilan psikomotor melibatkan penggunaan alat dan bahan, pengukuran, penyusunan atau perakitan alat dan keterampilan afektif, siswa akan berinteraksi dengan sesamenya dalam kegiatan belajar mengajar. Dengan demikian, jelaslah bahwa aspek proses dituntut dalam pembelajaran IPA. Sudah sewajarnya keterampilan proses menjadi bagian yang tak terpisahkan dari pembelajaran biologi. Hal ini disebabkan melalui KPS siswa mendapatkan pengalaman belajar secara utuh baik aspek kognitif, psikomotor maupun aspek afektif.

Untuk melaksanakan pembelajaran biologi dengan pendekatan KPS, dibutuhkan bahan ajar yang akan dijadikan pedoman bagi guru dalam melakukan pembelajaran, salah satunya adalah LKS. LKS merupakan materi ajar yang dikemas sedemikian rupa agar siswa dapat mempelajari materi tersebut secara mandiri (Sutanto, 2009:1). Lembar kegiatan ini dapat berupa panduan untuk latihan pengembangan aspek kognitif maupun panduan untuk pengembangan semua aspek pembelajaran dalam bentuk panduan eksperimen. LKS bertujuan untuk menemukan konsep atau prinsip dan aplikasi konsep atau prinsip. Selain itu dalam LKS dapat menemukan arahan yang alat bantu pembelajaran.

Hasil observasi lapangan menunjukkan LKS yang digunakan masih belum sesuai dengan pendekatan KPS. Untuk mengatasi permasalahan tersebut peneliti mencoba membuat suatu bahan ajar berupa LKS dengan pendekatan KPS untuk meningkatkan hasil belajar siswa.

Untuk mengembangkan LKS dengan pendekatan KPS berbasis lingkungan ini, peneliti memilih materi fotosintesis. Materi fotosintesis merupakan materi yang syarat akan pemahaman sehingga sulit dipahami oleh siswa. Hasil observasi di lapangan menunjukkan LKS materi fotosintesis belum tersedia sehingga guru hanya menyajikan materi dengan ceramah. Belum tersedianya LKS dan alat-alat praktikum merupakan salah satu penyebab kurangnya diaplikasikan kegiatan praktikum pada pembelajaran fotosintesis.

Berdasarkan uraian dari latar belakang yang dikemukakan di atas, dapat diidentifikasi beberapa masalah sebagai berikut:

1. Persepsi siswa bahwa mata pelajaran biologi merupakan materi teoritis bersifat hafalan sehingga terkesan kurang menarik dan tidak menyenangkan.

2. LKS yang beredar kurang menuntun siswa dalam melakukan percobaanpercobaan yang dapat menuntut siswa dalam memperoleh pengalaman langsung dari pembelajaran

3. Kegiatan percobaannya menggunakan alat-alat yang umumya tidak disesuaikan dengan alat yang tersedia di sekolah.

\section{METODE PENELITIAN}

Penelitian ini menggunakan metode Education Research and Development $(R \& D)$ yaitu pengembangan model pembelajaran IPA berorientasi pendekatan keterampilan proses sains melalui pengembangan LKS pada Mata Pelajaran IPA SMP. Oleh sebab itu, penelitian pengembangan ini berorientasi pada pengembangan produk dimana proses pengembangannya dideskripsikan seteliti mungkin dan produk akhirnya dievaluasi.

Model pengembangan ini adalah model pengembangan 4-D (four $D$ ) yang terdiri dari 4 tahap: pendefinisian (define), perancangan (design), pengembangan (develop) dan penyebaran (disseminate), namun pada penelitian ini peneliti hanya melakukan sampai pada tahap develop saja. Selanjutnya produk 
akan divalidasi oleh pakar, kemudian akan diuji coba pada siswa
Langkah-langkah rancangan pengembangan perangkat ini digambarkan seperti Gambar 1 berikut ini:

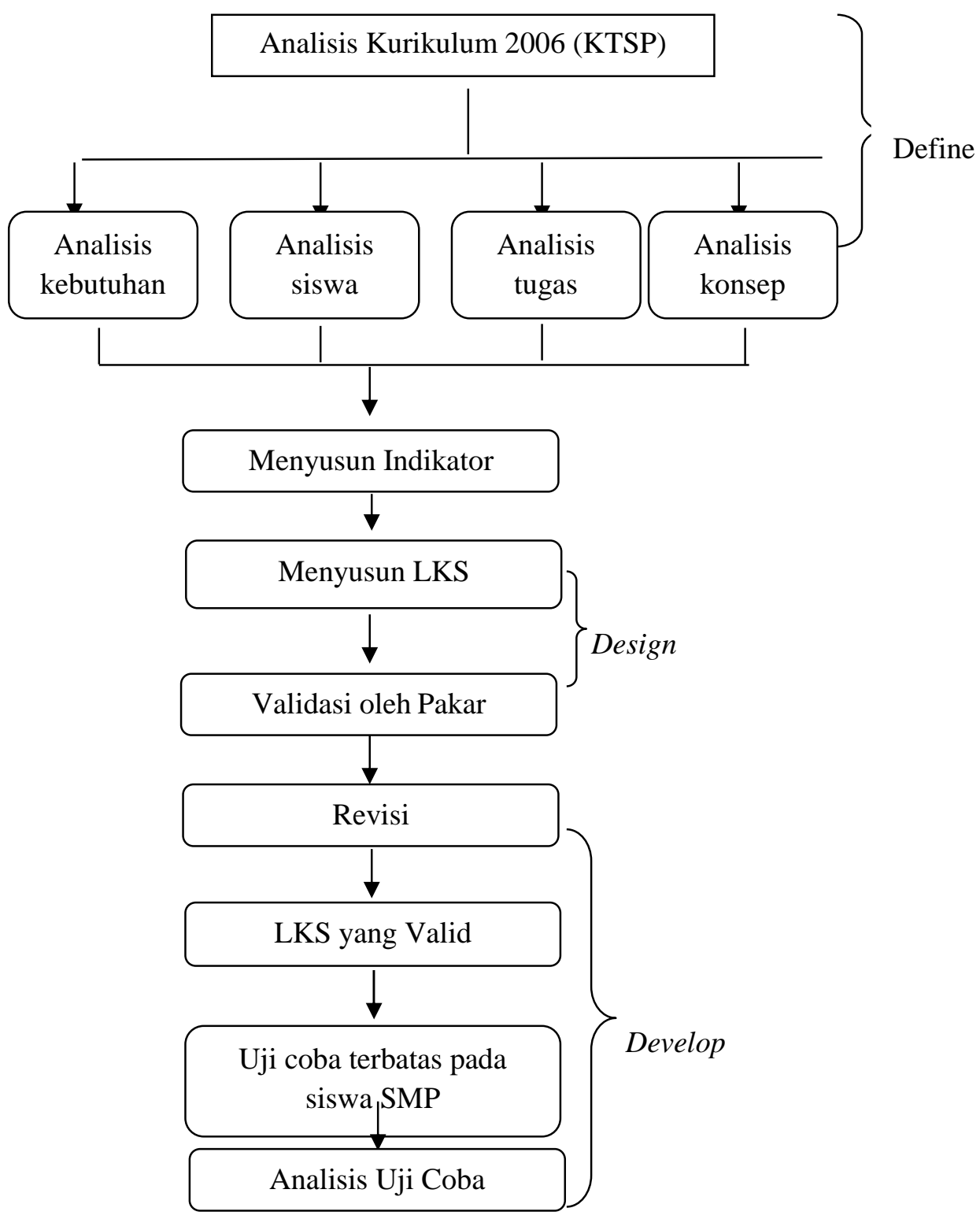

Gambar 1: Diagram rancangan pengembangan perangkat pembelajaran dengan pendekatan keterampilan proses sans berbasis lingkungan dimodifikasi dari Thiagarajan (1974 dalam Dyah, 2006:37)

Uji coba terbatas produk penelitian dilakukan di SMP Dedikasi Edukasi Kualiva (DEK) Padang pada siswa kelas VIII dan melibatkan guru IPA dalam melakukan penilaian terhadap produk perangkat pembelajaran yang disusun. Produk berupa LKS diuji melalui aktivitas siswa dan respon siswa terhadap kegiatan pembelajaran. Validitas LKS diukur dengan validasi isi dan konstruknya, yang dilakukan oleh pakar pendidikan dan praktisi pendidikan sesuai dengan bidang kajiannya. Analisis data dilakukan secara deskriptif. 
Data hasil validasi perangkat pembelajaran yang diperoleh, dianalisis terhadap seluruh aspek yang disajikan dalam bentuk tabel dengan menggunakan Skala Likert, selanjutnya dicari rerata nilai dengan menggunakan rumus berikut:

$$
\mathrm{R}=\frac{\sum_{\mathrm{j}=1}^{\mathrm{n}}}{\mathrm{nm}}
$$

(Muliyardi, 2006:82).

Dengan: $\quad \mathrm{R}=$ rerata hasil penilaian dari para ahli/praktisi

$\mathrm{V}_{\mathrm{ij}}=$ skor hasil penilaian para ahli/praktisi ke-j terhadap kriteria $i$

$\mathrm{n}$ = banyaknya para ahli/praktisi yang menilai

$$
\mathrm{m} \text { = banyaknya kriteria }
$$

Rerata yang didapatkan dikonfirmasikan dengan kriteria yang ditetapkan. Cara mendapatkan kriteria tersebut dengan menggunakan langkah sebagai berikut:

a. Rentangan skor mulai dari 0 - 4 . b. Kriteria dibagi atas 5 tingkatan, yaitu sangat valid, valid, cukup valid, kurang valid dan tidak valid.

c. Rentangan skor dibagi menjadi lima kelas interval.

Dengan mengikuti prosedur di atas didapatkan kriteria sebagai berikut:

a. Bila rerata > 3.20 maka dikategorikan sangat valid

b. Bila $2,40<$ rerata $\leq 3,20$ maka dikategorikan valid

c. Bila $1,60<$ rerata $\leq 2,40$ maka dikategorikan cukup valid

d. Bila $0,80<$ rerata $\leq 1,60$ maka dikategorikan kurang valid

e. Bila rerata $\leq 0,80$ maka dikategorikan tidak valid

\section{HASIL DAN PEMBASAN}

\section{Validitas LKS}

Data hasil validasi materi ajar dari validator ahli disajikan pada Tabel 1 di bawah ini.

Tabel 1. Hasil validasi LKS berorientasi pada pendekatan KPS

\begin{tabular}{lccc}
\hline No & Aspek yang dinilai & $\begin{array}{c}\text { Nilai } \\
\text { validasi }\end{array}$ & Kategori \\
\hline$(1)$ & $(2)$ & $(3)$ & $(4)$
\end{tabular}

\section{A. Syarat Didaktik}

\begin{tabular}{llcc}
\hline 1. & Kesesuain SK dan KD dengan isi. & 4 & Sangat valid \\
\hline 2. & Kesesuaian dengan kebutuhan siswa. & 3,7 & Sangat valid \\
\hline 3. & Kesesuaian dengan kebutuhan bahan ajar. & 3,7 & Sangat valid \\
\hline 4. & $\begin{array}{l}\text { Manfaat untuk penambahan wawasan } \\
\text { pengetahuan }\end{array}$ & 4 & Sangat valid \\
\hline 5. & $\begin{array}{l}\text { Kesesuaian dengan nilai-nilai moralitas dan } \\
\text { sosial. }\end{array}$ & 3,3 & Sangat valid \\
\hline & \multicolumn{1}{c}{ Rata-rata } & 3,7 & Sangat valid \\
\hline B. & Bahasa dan keterbacaan & 3 & Valid \\
\hline 6. & $\begin{array}{l}\text { Menggunakan kaidah bahasa Indonesia yang } \\
\text { baik dan benar. }\end{array}$ & 3 & Valid \\
\hline 7. & Menggunakan Ejaan Yang Disempurnakan. & 3 & Valid \\
\hline 8. & $\begin{array}{l}\text { Menggunakan istilah-istilah yang sesuai } \\
\text { dengan konsep yang menjadi pokok bahsan. }\end{array}$ \\
\hline
\end{tabular}




\begin{tabular}{|c|c|c|}
\hline $\begin{array}{l}\text { B. Bahasa yang digunakan sederhana, lugas, dan } \\
\text { mudah dipahami. }\end{array}$ & 3 & Valid \\
\hline Rata-rata & 3 & Valid \\
\hline \multicolumn{3}{|l|}{ C. Kegiatan } \\
\hline $\begin{array}{l}\text { Sesuai dengan konsep pelajaran yang } \\
\text { dipelajari. }\end{array}$ & 4 & Sangat valid \\
\hline 11. Melatih keterampilan proses yang beragam. & 3,3 & Sangat valid \\
\hline $\begin{array}{l}\text { Menunjang kelancaran keterlaksanaan } \\
\text { pembelajaran. }\end{array}$ & 3,3 & Sangat valid \\
\hline 13. Mudah dilaksanakan. & 3,3 & Sangat Valid \\
\hline 14. Mengundang keingintahuan siswa lebih lanjut. & 3,3 & Sangat valid \\
\hline 15. Penerapan untuk kehidupan sehari-hari. & 3 & Valid \\
\hline Rata-rata & 3,3 & Sangat valid \\
\hline \multicolumn{3}{|l|}{ D. Syarat teknis dan kontruksi } \\
\hline 16. Tujuannya diajabarkan dengan jelas. & 3,3 & Sangat valid \\
\hline $\begin{array}{l}\text { 17. Terdapat kegiatan yang berbasis keterampilan } \\
\text { proses. }\end{array}$ & 3,7 & Sangat valid \\
\hline $\begin{array}{l}\text { 18. Penyajian kegiatan menunjang keterlibatan } \\
\text { siswa secara aktif untuk mengemukakan ide } \\
\text { kreatif. }\end{array}$ & 3,7 & Sangat valid \\
\hline 19. Kegrafisan & 3 & Valid \\
\hline 20. Penggunaan font (jenis dan ukuran) huruf. & 3 & Valid \\
\hline Lay Out dan tata letak. & 3 & Valid \\
\hline Rata-rata & 3,3 & Sangat valid \\
\hline Jumlah & 207 & \multirow{2}{*}{ Sangat valid } \\
\hline Rata-rata nilai validasi & 3,33 & \\
\hline
\end{tabular}

Berdasarkan hasil validasi perangkat pembelajaran yang berorientasi pada pembelajaran dengan pendekatan KPS, dapat diketahui bahwa LKS yang dikembangkan memperoleh rata-rata nilai validasi LKS adalah 3,33 ketegori sangat valid. Hal ini berarti LKS yang dikembangkan sudah baik dan dapat digunakan sebagai sumber belajar bagi siswa dalam proses pembelajaran yang berorientasi pada KPS. LKS yang dikembangkan merupakan panduan bagi siswa dalam melakukan kegiatan praktikum.

Validasi yang dilakukan pada penelitian ini menekankan pada validitas isi dan validitas konstruksi. Menurut Riduwan (2008:97) untuk menguji validitas konstruksi (contruct validity) dapat dilakukan dengan meminta pendapat dari ahli (judgment expert). Setelah penguji- an konstruksi selesai dari para ahli, maka diteruskan dengan uji coba. Validitas isi dinyatakan valid oleh validator karena perangkat pembelajaran yang dikembangkan telah sesuai dengan materi yang seharusnya disajikan. Sedangkan validasi konstruksi menurut Riduwan (2008: 97) "untuk menguji validitas konstruksi (construct validity), dapat digunakan pendapat dari ahli (judgment validity)".

\section{Respon Siswa}

Respon siswa setelah proses pembelajaran yang berorientasi pada pendekatan keterampilan proses sains, baik di kelas VIII.1 dan kelas VIII.2 SMP DEK Padang secara umum sangat baik. Hal ini ditunjukkan oleh data angket respon yang di isi oleh siswa di kedua kelas tersebut. Siswa senang dan antusias dalam mengikuti proses pembelajar- 
an menggunakan perangkat pembelajaran dengan pembelajaran dengan pendekatan keterampilan proses sains, karena mereka diberi kesempatan untuk belajar tidak hanya di dalam ruangan tapi juga di luar ruangan.

Pada proses pembelajaran yang dilakukan didominasi dengan kegiatan siswa seperti: kegiatan praktikum dengan menggunakan alat dan bahan yang mudah diperoleh dari lingkungan sehingga siswa memperoleh pengalaman langsung. Menurut Lufri (2007:36) dengan menggunakan metode eksperimen siswa tidak hanya menelan saja sejumlah teori atau informasi yang diperoleh dalam pembelajaran, tapi siswa mengalami sendiri, sehingga dapat mengembangkan sikap ilmiah, siswa lebih percaya atas kebenaran konsep berdasarkan percobaan.

\section{Hasil Belajar}

\section{Aspek kognitif}

Untuk mengetahui seberapa jauh siswa dapat menguasai materi ajar, maka dilakukan tes hasil belajar pada aspek kognitif. Pemberian tes dilakukan satu kali, yaitu tes formatif yang dilakukan setelah kegiatan pembelajaran dilaksanakan. Hasil yang diperoleh siswa secara individual akan dibandingkan dengan KKM yang telah ditentukan. KKM adalah krikeria ketuntasan minimal yang ditentukan oleh satuan pendidikan. Pada materi fotosintesis ini KKM yang diberlakukan untuk kelas VIII.1 adalah 65 dan kelas VIII.2 adalah 60. Perbedaan nilai ini terjadi karena adanya perbedaan kemampuan siswa (intake) pada kelas uji coba. Menurut Sulistyowati (2007) dalam kriteria penetapan KKM perlu memperhatikan kompleksitas (kesulitan dan kerumitan), daya dukung dan intake siswa.

Hasil belajar aspek kognitif diperoleh dari nilai rata-rata kelas yang dibandingkan dengan KKM 65, yaitu
80,87. Dari 23 orang siswa kelas VIII.1 yang mengikuti evaluasi, 21 orang siswa secara individual dinyatakan tuntas dan 2 orang siswa belum mencapai ketuntasan minimal $(\mathrm{KKM}=65)$ sehingga dinyatakan belum tuntas. Demikian juga pada siswa kelas VIII.2 dari 22 orang siswa yang mengikuti evaluasi secara individual telah tuntas sebanyak 20 siswa dan 2 siswa belum mencapai ketuntasan.

Pada kegiatan tindak lanjut, siswa yang tidak tuntas dibelaki kembali dengan indikator yang belum tuntas untuk dilakukan remedial hingga mencapai ketuntasan. Bila dilihat secara klasikal pembelajaran biologi dengan menggunakan perangkat pembelajaran berorientasi keterampilan proses dapat dikatakan tuntas. Sehingga dapat disimpulkan bahwa pembelajaran dengan pendekatan keterampilan proses sains berbasis lingkungan pada materi fotosintesis dapat meningkatkan hasil belajar siswa.

\section{Aspek psikomotor}

Hasil belajar pada aspek psikomotor diperoleh melalui pengamatan terhadap kinerja siswa pada saat mengikuti pembelajaran selama uji coba perangkat pembelajaran berupa LKS dengan pendekatan KPS Pada pertemuan kedua (praktikum pertama) dilakukan saat siswa melaksanakan kegiatan praktikum yang bertujuan untuk menyelidiki terbentuknya gas oksigen dari proses fotosintesis. Sedangkan pada pertemuan ketiga (praktikum kedua) saat siswa melaksanakan kegiatan praktikum yang bertujuan untuk membuktikan pengaruh karbondioksida, cahaya dan klorofil pada proses fotosintesis.

Pada praktikum pertama hasil belajar pada aspek psikomotor siswa kelas $\mathrm{VIII}_{1}$, diketahui hampir semua kelompok mendapatkan nilai $\geq 80$ dengan kategori sangat baik Sedangkan hasil belajar pada aspek psikomotor siswa kelas $\mathrm{VIII}_{2} \quad 3$ kelompok mendapatkan nilai $\geq 80$ dengan kategori sangat baik dan 2 ke- 
lompok lainnya mendapatkan nilai masing-masing yaitu 76,56 dan 78,12. Namun, masih berada pada kategori sangat baik seperti Gambar 2 di bawah ini:

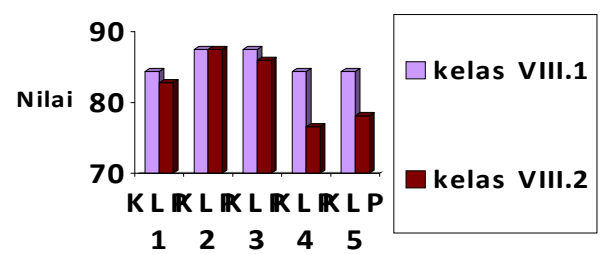

Gambar 2: Hasil psikomotor siswa dalam proses pembelajaran dengan pendekatan KPS berbasis lingkungan.

Dari Gambar 2 diketahui hasil belajar pada aspek psikomotor siswa di kedua kelas tersebut secara klasikal dapat dikatakan sangat baik. Hal ini dikarenakan penilaian dilakukan terhadap kinerja kelompok atau kooperatif, sehingga nilai individu juga menjadi baik. Menurut Slavin (2009:81) tujuan kelompok memberikan insentif kepada siswa untuk saling membantu satu sama lain dan untuk mendorong untuk melakukan usaha yang maksimal. Nilai siswa cukup baik sebagai kelompok hanya akan berhasil jika semua anggotanya telah mempelajari materinya dan anggota kelompok akan termotivasi untuk saling mengajarkan. Ini berarti, penerapan perangkat pembelajaran biologi beriorientasi pendekatan keterampilan proses sains berbasis lingkungan pada materi fotosintesis yang dikembangkan, mempunyai efek positif terhadap peningkatan hasil belajar siswa.

\section{Aspek afektif}

Hasil belajar aspek afektif diperoleh dari pengamatan terhadap sikap siswa selama pembelajaran dengan pendekatan KPS berbasis lingkungan ber- langsung. Siswa kelas VIII 1 memperoleh nilai rata-rata 87,39 pada pertemuan pertama, 84,56 pada pertemuan kedua dan 90,43 pada pertemuan ketiga. Sedangkan siswa kelas $\mathrm{VIII}_{2}$ memperoleh nilai rata-rata 80,23 pada pertemuan pertama 84,54 pada pertemuan ke dua dan 86,36 pada pertemuan ketiga.

Hasil belajar ini menunjukkan sikap siswa dalam pembelajaran termasuk dalam kategori sangat baik. Artinya siswa mampu bersikap secara ilmiah selama mengikuti pembelajaran dengan pendekatan keterampilan proses sains berbasis lingkungan, meliputi membawa semua perangkat pembelajaran, menyimak dan memperhatikan penjelasan guru, berpartisipasi dalam diskusi kelompok, berperan aktif dalam praktikum, tertib dan bersih dalam kegiatan praktikum dan berani mengemukakan pendapat. Hal ini sesuai dengan tujuan pembelajaran sains biologi, yaitu memupuk sikap ilmah; jujur, terbuka, ulet, kritis dan mampu bekerja sama dengan orang lain (Depdiknas, 2006:451).

Pelaksanaan pembelajaran dengan pendekatan keterampilan proses selain keterampilan intelektual dan fisik, keterampilan sosial juga dapat dilatihkan. Hal tersebut sesuai dengan pernyataan Depdiknas (Dimyati dan Mudjiono, 2009:138) pendekatan keterampilan proses dapat diartikan sebagai wawasan atau anutan pengembangan keterampilan-keterampilan intelektual, fisik, dan sosial. Sehingga dapat disimpulkan kegiatan pembelajaran dengan menggunakan perangkat pembelajaran dengan pendekatan keterampilan proses mempunyai efek positif terhadap peningkatan hasil belajar siswa pada aspek afektif.

\section{KESIMPULAN}

Berdasarkan uji coba LKS yang telah dilakukan diperoleh kesimpulan sebagai berikut: 
1. Dihasilkan LKS dengan validitas ratarata baik

2. Respon siswa terhadap pembelajaran dengan LKS berorientasi pada pendekatan KPS berbasis lingkungan positif. Siswa merasa antusian dan senang dalam mengikuti pembelajar-

\section{DAFTAR RUJUKAN}

Anonim. 2009a. Hakekat IPA, (Online http://6ckeren.blogspot.com/2009/ 01/hakekat-ipa.html, diakses 27 Juni 2009)

Badan Standar Nasional Pendidikan. 2006. Model Silabus dan Rencana Pelaksanaan Pembelajaran. Jakarta: Departemen Pendidikan Nasional

Departemen Pendidikan Nasional. 2006. Model Pembelajaran Terpadu IPA Jakarta : Depdikna

Dimyati dan Mujiono. 2009. Belajar dan Pembelajaran. Jakarta: Rineka cipta

Dyah Astriani. 2006. "Implementasi Metode Inkuiri dalam Pembelajaran Biologi dengan Setting Pembelajaran Kooperatif di MAN Surabaya". Tesis tidak diterbitkan. Surabaya: Universitas Negeri Surabaya.

Lufri. 2007. Strategi Pembelajaran Biologi Teori, Praktik dan Penelitian. Padang : UNP Press

Muliyardi. 2006. "Pengembangan Model Pembelajaran Matematika Menggunakan Komik di Kelas 1 Sekolah Dasar". Disertasi tidak diterbitkan. Surabaya: Universitas Negeri Surabaya.

Riduwan. 2006. Belajar Mudah Penelitian untuk Guru, Karyawan dan an dengan menggunakan perangkat pembelajaran dari guru.

3. Hasil belajar siswa setelah belajar dengan dengan LKS berorientasi pada pendekatan KPS berbasis lingkungan baik.

Peneliti Pemula. Bandung: Alfabeta.

Rustaman. 2003. Strategi Belajar Mengajar Biologi Common Text Book Edisi Revisi. Jakarta: Universitas Negeri Indonesia

Saleh.2007. Pembelajaran Matematika Realistik Untuk Topik Persegi panjang Dan Persegi Di Kelas VII SMP Negeri 9 Kendari. Jurnal Mathedu, Vol. 2, Suplemen, Nopember 2007. Kendari : Jurusan Pendidikan MIPA Universitas Haluoleo.

(http://lib.unhalu.ac.id/files/Saleh/ Artikelupload.pdf. Diakse 22 Juni 2009).

Slavin,R. 2009. Cooperatif Learning Teori, Riset dan Praktik cetakan kelima. Bandung : Nusa Media.

Sudijono,A. 2008. Pengantar Evaluasi Pendidikan. Jakarta: Raja Grafindo Persada.

Sulistyowati. 2007. Kriteria Ketuntasan Minimal. Jakarta: Pusat Kurikulum Balitbang Depdiknas (Di sampaikan pada workshop MGMP di Padang)

Sutanto, P.2009.Pemanfaatan dan Pengembangan LKS dalam Pembelajaran.

(www.blogguru.net.Blogsweblog

Diakses 27 Juni 2009).

Biologi, 2, 9, 10

Daftar Indeks

biologi, 2, 3, 8, 9 
guru, 2, 3, 5, 9

ilmiah, 1, 2, 7, 9

ilmu, 1, 2

pembelajaran, 1, 2, 3, 4, 5, 6, 7, 8, 9

peserta, 2, 3 proses, 1, 2, 3, 4, 5, 6, 7, 8, 9

sains, 1, 2, 4, 7, 8, 9

Sekolah, 1

Siswa, 7, 8, 9

teknologi, 1, 2 